\title{
Rewiring Empathy: \\ The Value of Multicultural Literature in the Classroom
}

\author{
Heather Conrad \\ Lightport Books, United States
}

\begin{abstract}
Reading multicultural novels cultivates empathy for diverse people, cultures, and environments in ways that Internet use cannot. The act of reading fictional books has been shown to increase the capacity for empathy in the reader. Internet use, by contrast, has been shown to reduce students' ability to remember, concentrate, and engage in the deep reading and contemplation activity that develops empathy. Empathy is vital to our global future. Hate crimes are increasing in the United States, United Kingdom, and elsewhere; worldwide, the number of political and climate-change refugees is increasing and the biodiversity of other species is declining. Addressing these problems requires an increase in human empathy and cooperation. Therefore multicultural books are vital to preparing students for our changing world. It is up to schools to discover, acquire, and prioritize multicultural books in the classroom.
\end{abstract}

\section{Keywords: Multiculturalism, Multicultural Fiction, Internet, Hate Crimes, Diversity, Children's Literature, Empathy}

\section{INTRODUCTION}

On September 30, 2016, the historic Ashburn Colored School in Virginia, where African American children were educated from 1892 until the 1950s, was vandalized. Five teenaged boys painted swastikas, obscenities, and the words "white power" on the old wooden walls of the one-room building. Judge Avelina Jacob, of the Juvenile and Domestic Relations District Court, sentenced the boys who committed the crime. Her sentence: they must each read one book per month from a list of multicultural literature that included The Kite Runner, Schindler's List, and Things Fall Apart (Scott, 2017).

What is the value of multicultural literature in 21 st-century schools? What effect does reading literature by and about people from other cultures have on the decisions future adults will make? And how important is it for young people to read books at all in the age of the Internet?

\section{Literature}

\section{LITERATURE VERSUS THE INTERNET}

Within the past decade, a remarkable body of research has emerged providing evidence that the reading of fiction develops a capacity for empathy in the reader, and that this capacity carries over into real-life situations.

In "Novel finding: Reading literary fiction improves empathy," Julianne Chiaet summarizes the conclusions of five studies done by researchers at the New School in New York City (Chiaet, 2013). The studies provide "evidence that literary fiction improves a reader's capacity to understand what others are thinking and feeling." Because literature focuses on the psychology of characters and their relationships, rather than formulaic plots, literary fiction tends to be more realistic than genre fiction. The act of reading about complex characters and trying to understand their motivations can undo prejudices and stereotypes. The characters in literary fiction "support and teach us values about social behavior, such as the importance of understanding those who are different from ourselves," Chiaet states.

In "Can reading a fictional story make you more empathetic?" Christopher Bergland describes the results of a Carnegie Mellon brain mapping experiment (Bergland, 2014). Neuroscientists discovered that reading about the activity of a fictional character activates the same brain areas as actually performing or witnessing the activity in real life. As Bergland states, "In reading a fictional story your brain is literally 
living vicariously through the characters at a neurobiological level. . . . [It] appears to improve the reader's ability to put themselves in another person's shoes and flex the imagination in a way that is very similar to the visualization that an athlete would use to activate the motor cortex and muscle memory used in sports during a mental rehearsal." In this study, it is not simply literary fiction that leads to the ability to put oneself in another person's shoes, but fiction in general.

In "How fiction might improve empathy," Honor Whiteman discusses an article in the journal Trends in Cognitive Sciences by Keith Oatley, of the Department of Applied Psychology and Human Development at the University of Toronto (Whiteman, 2016). According to Whiteman, Oatley presents findings from previous studies, as well as his own recent study, on how "literary fiction influences readers' empathetic response in the real world." He points out that fiction is a "simulation of social worlds," and that, "similar to people who improve their flying skills in a flight simulator, those who read fiction might improve their social skills. Fiction might be the mind's flight simulator." Whiteman writes that Oatley "describes previous research that showed readers of a book called Saffron Dreams-a fictional story of a Muslim woman in New York-had greater empathy for people of a different race/ethnicity, compared with those who did not read a fictional book."

Many more studies exist which show that reading that involves imagining a fictional character's experience trains the reader to use brain functions that produce empathetic responses toward others. For readers of multicultural literature, this includes empathy towards persons of other cultures and races.

\section{THE INTERNET}

Much of what informs our current views on education and psychology is contemporary brain research. Although William James observed over one hundred years ago that "the nervous tissue seems endowed with a very extraordinary degree of plasticity" (James, 1892), the fact of the brain's plasticity was not proven or accepted until very recently. In the past, almost everyone from Kant to Chomsky believed that the brain was hard-wired and remained so from a very early age. Within the last few decades, however, advanced brain research has proven that the brain is very plastic. "Today, scientists sum up the essential dynamic of neuroplasticity with a saying known as Hebb's rule: 'Cells that fire together wire together" (Carr, 2011, p. 27). In other words, performing repeated actions and behaviors, at any point in life, burns neural pathways in the brain that become wired-become habit. And further, burning new neural pathways can reduce the efficacy of previous neural pathways. Developing new brain habits can replace old brain habits. This rewiring of the brain occurs when we use the Internet.

According to a study conducted at Washington University's Dynamic Cognition Laboratory and published in Psychological Science in 2009, when reading a story, "readers mentally simulate each new situation encountered in a narrative. Details about action and sensation are captured from the text and integrated with personal knowledge from past experiences" (Carr, 2011, p. 74). The Internet, however, presents text in a way that interrupts this process. Concentration and the ability to have a deep reading experience are disrupted by the Internet's multimedia, multistimulus, or "hypermedia" presentation. Hypermedia is full of links, images, animation, and an entire "ecosystem of interruption technologies" (Carr, 2011, p. 91). These stimuli can adversely affect memory.

Human memory has two functional components: short-term, or "working memory," and longterm memory. Modern neuroscientific research has shown that, while long-term memory has unlimited storage capacity (the brain literally grows new synapses to create more long-term memory), our working memory is very limited. We can process only two or three things at a time in our working memory, and these things will quickly vanish if we do not process them in the way that will store them in long-term memory-a complex process that takes time. The information in our working memory at any given moment is called "cognitive load." As Carr explains, "When the load exceeds our mind's ability to store and process the information ... we're unable to retain [it] or to draw connections with the information already stored in our long-term memory. We can't translate the new information into schemas. Our ability to learn suffers, and our understanding remains shallow" (Carr, 2011, p. 125).

Several recent studies have shown that when students read an article with hypertext and multiple distracting images, even when those images are related to the article's content, the students comprehend 
and retain less than do those who read the article in a pure text format. Carr describes one such study, performed by Erping Zhu: "She had groups of people read the same piece of online writing, but she varied the number of links included in the passage. She then tested the readers' comprehension by asking them to write a summary of what they had read and complete a multiple-choice test. She found that comprehension declined as the number of links increased" (Carr, 2011, p. 128).

Dr. Zhu concluded that "reading and comprehension require establishing relationships between concepts, drawing inferences, activating prior knowledge, and synthesizing main ideas. Disorientation or cognitive overload may thus interfere with cognitive activities of reading and comprehension" (Carr, 2011, p. 129). As Carr states, "The Net is, by design, an interruption system, a machine geared for dividing attention. That's not only a result of its ability to display many different kinds of media simultaneously. It's also a result of the ease with which it can be programmed to send and receive messages. ... Studies of office workers who use computers reveal that they constantly stop what they're doing to read and respond to incoming emails. It's not unusual for them to glance at their in-box thirty or forty times an hour" (Carr, 2011, p. 132).

Having our attention drawn to multimedia images, incoming messages, hyperlinks, or so-called click bait demands that we refocus our mental energy from a contemplative state (if we are reading, writing, or thinking deeply) to a more hyper state that demands a quick decision on whether to click the link, icon, message, or whatever has grabbed our attention. Literally our brain must stop the calm, contemplative process of communication between working and long-term memory, and jump to the executive function in the prefrontal cortex to make a decision every time we hear a beep or ringtone or see a flashing image or colorful link. "The redirection of our mental resources, from reading words to making judgments may be imperceptible to us . . . but it's been shown to impede comprehension and retention, particularly when it's repeated frequently .... our brains become not only exercised but overtaxed" (Carr, 2011, p. 122).

In addition, some studies indicate that Internet use can be addictive. As Adam Alter, author of Irresistible: The rise of addictive technology and the business of keeping us hooked, says about the Internet, "The technology is designed to hook us . . . Email is bottomless. Social media platforms are endless. Twitter? The feed never really ends. And so you come back for more and more" (Dreifus, 2017). He also states, "I find it interesting that the late Steve Jobs said in a 2010 interview that his own children didn't use iPads. In fact there are a surprising number of Silicon Valley titans who refuse to let their kids near certain devices."

As Carr states, "The Net's cacophony of stimuli short-circuits both conscious and unconscious

thought, preventing our minds from thinking either deeply or creatively. Our brains turn into simple

signal-processing units, quickly shepherding information into consciousness and then back out again"

(Carr, 2011, p. 119). In other words, those brain processes involved in creativity, imagination, deep reading, and the development of empathy are replaced with "signal-processing."

\section{HATE CRIMES}

The vandalizing of the historic African American schoolhouse in Ashburn is one of an increasing number of hate crimes in the United States. The Hate Crime Statistics Act of 1990 defines hate crimes as "crimes that manifest evidence of prejudice based on race, gender or gender identity, religion, disability, sexual orientation, or ethnicity" (U.S. Department of Justice, Federal Bureau of Investigation, 2010). While hate crime rates remained relatively steady over the past decade (Ingraham, 2015), they are now on the rise. According to USA Today, "the FBI reported hate crime incidents in 2015 increased by nearly 7\%, driven by a $67 \%$ surge in such offenses targeting Muslims. .. . The FBI report also showed increases in the number of hate crimes committed against Jewish people, African Americans, and LGBT individuals" (Johnson, 2016). While national hate crime statistics for the year 2016 are not available as of this writing, the New York City Police Department reported a 35\% increase in hate crimes in New York City in 2016 (Economist, 2016).

On February 15, 2017, the Southern Poverty Law Center reported that in their 2016 survey of ten thousand educators, "Eighty percent described heightened anxiety and fear among students, particularly 
immigrants, Muslims and African Americans. Numerous teachers reported the use of slurs, derogatory language and extremist symbols in their classrooms" (Southern Poverty Law Center, 2017).

The rise in hate crimes nationally, and the prejudice which those crimes manifest, must be of great concern to educators. These acts indicate a backwards momentum, a return to fear and ignorance in regard to other cultures. This regression is also occurring outside the United States. In February 2017, The Guardian reported that "the number of anti-Semitic incidents in the UK rose by more than a third to record levels in 2016, according to data released by the Community Security Trust" (Sherwood, 2017). UK government statistics from July 2016 showed that hate crimes had increased 19\% from the previous year and that "79\% [of those crimes] were motivated by race hate" (BBC, 2016). On May 6, 2016, the organization Human Rights First reported that a new French report, by the Commission Nationale Consultative des Droits de l'Homme, showed a rise in the number of attacks on Muslims in France, as well as sustained targeting of Jews (BBC, 2017).

Behind each of these abstract statistics is a story of hurt and harm. On November 9, 2016, at Royal Oak Middle School in Michigan, a group of students turned the cafeteria into a frightening scene for the Hispanic children eating there. Students began pounding on the tables with their hands and chanting "Build a wall, build a wall," referring to President Trump's promise to build a 2,000-mile wall along the southern U.S. border to keep Mexicans out. One of the Hispanic students, Josie, a 12-year-old girl, took a seven-second video of the scene that was later viewed by millions worldwide. One of her friends had run from the building crying and other Hispanic students were also crying and frightened. In the weeks that followed, Josie, an A-student, was ostracized and eventually withdrew from Royal Oak Middle School. She had been criticized not just by other students but also some parents for shedding light on what took place in the lunchroom that day. Josie said the cafeteria incident wasn't the first time she and her friends had experienced racism at the school. "I've had people make jokes about me and my culture," Josie said. They make jokes about Mexicans. They make jokes about blacks. And it's disheartening, and it hurts me physically" (Wallace \& LaMotte, 2016).

It's disheartening, and it hurts her physically. Why couldn't the chanting children feel empathy for the Hispanic children's suffering? What kind of social climate leads to racial scapegoating? Where will this kind of behavior lead? How can it be prevented?

\section{OUR GLOBAL FUTURE}

The U.S. Department of Justice reports that the motives of those who commit hate crimes are "thrillseeking," protecting "turf," and "scapegoating" inspired by "resentment about the growing economic power of a racial or ethnic group" (U.S. Department of Justice, 2001).

Protecting turf and scapegoating are on the rise in many parts of the world. For example, in the United States and Europe there are growing movements seeking to preserve a white, Christian national identity. Nonetheless, the world's diverse peoples are increasingly mobile and intermixed. Efforts to reverse the internationalist trend with travel bans, border walls, and withdrawal from international alliances will not halt the fact that the number of global travelers, migrants, and refugees is increasing worldwide and will continue to do so.

In the United States alone, the non-Hispanic white population is steadily decreasing. Whites were $80 \%$ of the population in 1980 , and down to $69 \%$ in 2000 , according to data from the U.S. Census Bureau; projections conclude that "the U.S. is on track to becoming a majority-minority country by 2043" (Walsh, 2013).

More significantly, worldwide refugee populations are increasing dramatically. In 2014, nearly 60 million people fled war and persecution in their homelands, more than in any year since the United Nations began keeping records. In 2015, the number of displaced persons increased again, to 65 million (Negin, 2016).

Not only are the numbers of war refugees increasing, but also climate change is projected to vastly increase the number of displaced peoples. A "study in the British Royal Society's scientific journal estimated that 72 million to 187 million people would be displaced by the year 2100 if no action is taken to upgrade coastal defenses" against rising sea levels (Negin, 2016). This process has already begun. Last 
year, the Alaskan village of Shishmaref voted to abandon its ancestral home because their "tiny island had lost nearly 3,000 feet of land to coastal erosion since 1980" (Visser \& Newsome, 2016).

Lastly, our human society is also threatened by the disregard for diversity of other species. "An international team of scientists [in 2016] . . . issued a warning that biodiversity is dropping below safe levels for the support and wellbeing of human societies" (Thompson, 2016). A recent two-year UN study found that, as the Associated Press summarized, "Many species of wild bees, butterflies and other critters that pollinate plants are shrinking toward extinction, and the world needs to do something about it before our food supply suffers" (Bornstein, 2016).

As a global society it will be fatal to shut down empathy, and to commit acts of violence and aggression against people different from ourselves. Diversity is essential to life and society, and empathy is essential to sustaining diversity. Multicultural literature and picture books often depict biological as well as cultural diversity and foster an appreciation for the wonderful variety of life on Earth. If we inspire schoolchildren to love the natural environments and peoples of the world, their generation may enjoy them, and we can hope, save themselves.

\section{CONCLUSION}

As Carl Sagan said about preserving life on earth, "There is no place else, at least in the near future, to which our species could migrate" (Sagan, 1994). Climate change is creating more refugees from diverse cultures and more plant and animal species extinction. The need for greater integration of cultures and shared resources will only increase.

Dana Mortenson, one of the confounders of World Savvy, an organization working to develop global competence in children's education, asks "What are the values, attitudes, skills and behaviors that must be cultivated if we're going to live in a peaceful world?" Her answer is that "what's needed is . . . an openness to new opportunities and ideas. . . . It's self-awareness about culture and respect for different perspectives. .. . Empathy and humility are big pieces of all of it" (Bornstein, 2017).

While only $22 \%$ of children's books published in the United States last year had any black, Latino, Native American, or Asian Pacific American characters (Donnella, 2017), many multicultural resources do exist. The Empathy Lab in Britain (www.empathylab.uk) recommends several books, including The Colour of Home by Mary Hoffman, about a Somali child thrown into a foreign school environment, alone and without a friend, and Mirror, by Jeannie Baker, a picture book without words that portrays the lives of an Australian boy and a Moroccan boy and all the differences and similarities of their lives. At the Stone Center at Wellesley College, the nonprofit Open Circle (www.open-circle.org) promotes "children's literature that supports social and emotional learning." One of their book lists focuses on "the ability to take the perspective of and empathize with others." They suggest titles such as $I$ Lost My Tooth in Africa by Penda Kiakite and I Love Saturdays y Domingos by Alma Flor Ada. Thousands of multicultural picture books and young adult novels exist. It is up to our schools to discover and acquire them, and to prioritize the value of reading them.

Reading fiction cultivates empathy in a way that Internet use cannot. Reading multicultural fiction expands that empathy to a variety of people and environments. This is essential to human survival in our changing world.

\section{REFERENCES}

BBC. (2016, October 13). Race and religious hate crimes rose $41 \%$ after EU vote. BBC News. Retrieved from http://www.bbc.com/news/uk-politics-37640982.

BBC. (2017, February 15). 'Record hate crimes' after EU referendum. BBC News. Retrieved from http://www.bbc.com/news/uk-38976087.

Bergland, C. (2014, December 1). Can reading a fictional story make you more empathetic? Psychology Today (blog). Retrieved from https://www.psychologytoday.com/blog/the-athletesway/201412/can-reading-fictional-story-make-you-more-empathetic. 
Bornstein, D. (2017, February 8). Preparing young Americans for a complex world. New York Times. Retrieved from https://www.nytimes.com/2017/02/08/opinion/preparing-young-americans-for-acomplex-world.html.

Bornstein, S. (2016, February 26). UN-sponsored scientific report warns too many species of pollinators are nearing extinction. U.S. News and World Report. Retrieved from https://www.usnews.com/news/world/articles/2016-02-26/un-science-report-warns-of-fewerbees-other-pollinators.

Carr, N. (2011). What the Internet is doing to our brains: The shallows. New York, NY: Norton.

Chiaet, J. (2013, October 4). Novel finding: Reading literary fiction improves empathy. Scientific American. Retrieved from https://www.scientificamerican.com/article/novel-finding-readingliterary-fiction-improves-empathy/.

Donnella, L. (2017, February 17). People of color accounted for 22 percent of children's books characters in 2016. National Public Radio. Retrieved from http://www.npr.org/sections/codeswitch/2017/02/17/515792141/authors-and-illustrators-of-coloraccounted-for-22-percent-of-children-s-books.

Dreifus, C. (2017, March 7). Why we can't look away from our screens. New York Times. Retrieved from https://www.nytimes.com/2017/03/06/science/technology-addiction-irresistible-by-adamalter.html.

Economist. (2016, December 10). By the numbers. The Economist. Retrieved fromwww.economist.com/news/united-states/21576694-cities-are-finding-useful-ways.

Ingraham, C. (2015, June 18). The ugly truth about hate crimes: In 5 charts and maps. The Washington Post (blog). Retrieved from https://www.washingtonpost.com/news/wonk/wp/2015/06/18/5charts-show-the-stubborn-persistence-of-american-hate-crime/?utm_term=.ebf969f2a766.

James, W. (1892). Writings 1878-1899: Psychology: Briefer course. New York, NY: Library of America.

Johnson, K. (2016, November 18). FBI investigating suspected post-election hate crimes. USA Today. Retrieved from https://www.usatoday.com/story/news/2016/11/18/fbi-investigating-post-electionhate-incidents-ag-lynch-says/94073332/.

Negin, E. (2016, June 30). Think today's refugee crisis is bad? Climate change will make it a lot worse. Huffington Post (blog). Retrieved from http://www.huffingtonpost.com/elliott-negin/thinktodays-refugee-cris_b_7691330.html.

Sagan, C. (1994). Pale blue dot: A vision of the human future in space. New York, NY: Random House.

Scott, S. (2017, February 8). Teens sentenced to read diverse books for vandalism charges. CNN. Retrieved from http://www.cnn.com/2017/02/08/health/diverse-books-sentence-vandalism-trnd/.

Sherwood, H. (2017, February 1). Reports of antisemitic incidents increase to record levels in UK. Guardian. Retrieved from https://www.theguardian.com/world/2017/feb/02/reports-ofantisemitic-incidents-increase-to-record-levels-in-uk.

Southern Poverty Law Center. (2017, February 15). Hate groups increase for second consecutive year as Trump electrifies radical right. Intelligence Report. Retrieved from https://www.splcenter.org/news/2017/02/15/hate-groups-increase-second-consecutive-yeartrump-electrifies-radical-right.

Thompson, R. (2016, July 15). Scientists warn of 'unsafe' decline in biodiversity. BBC News. Retrieved from http://www.bbc.com/news/science-environment-36805227.

U.S. Department of Justice. (2001). Hate crime: The violence of intolerance. Washington, DC: Community Relations Service, U.S. Department of Justice.

U.S. Department of Justice, Federal Bureau of Investigation. (2010). Hate crime statistics. Retrieved from https://ucr.fbi.gov/hate-crime/2010.

Visser, Steve, and Newsome, John. (2016, August 18). Alaskan village votes to relocate over global warming. $C N N$. Retrieved from http://www.cnn.com/2016/08/18/us/alaskan-town-votes-tomove/. 
Wallace, Kelly, and LaMotte, Sandee. (2016, December 28). The collateral damage after students' "build a wall" chant goes viral. CNN. Retrieved from http://www.cnn.com/2016/12/28/health/build-awall-viral-video-collateral-damage-middle-school/.

Walsh, M. (2013, June 13). U.S. percentage of non-Hispanic whites hits all-time low of 63\%. Daily News. Retrieved from http://www.nydailynews.com/news/national/percentage-non-hispanic-whites-hitsall-time-63-article-1.1371772.

Whiteman, H. (2016, July 20). How fiction might improve empathy. Medical News Today. Retrieved from http://www.medicalnewstoday.com/articles/311773.php. 